\title{
Searching for Ethical Hope: Ideas on what Feminist Debates on the Anthropocene can offer Theorisations of Gender and Violence
}

\author{
Jane Bennett $1 *$
}

Published: March 5, 2021

\begin{abstract}
This article reviews some contemporary responses by feminists such as Haraway and Braidotti to the invitations offered by the concept of the Anthropocene to reimagine the human and the violent. Finding the need to think more closely about questions of race and rape, in these responses, the article turns to the theory of Sylvia Wynter and the poetry of Yvette Christiansë for a rich enough language. The article then moves to the consideration of how to use such a language in the understanding of a particular ampersand the \& of gender and violence. The article is shaped as an exercise to trying to think, across contradictions and myriad accountabilities.
\end{abstract}

Keywords: race, Anthropocene, Slavery, feminist theory, gender and violence

\author{
Es la desaparición \\ Es la violación \\ From 'Un violador en tu camino', Las Tesis, Rita Segato \\ (bttps: / wmm.youtube.com/ watch? $v=$ uSHUS2lebOY)
}

\begin{abstract}
Do not hear what others say - / that we are sad creatures/clad in uniforms of loss:/ blue skirts that bruise/the heels of those who are living/but are dead. We live, we live 'Spoken, a message home', Yvette Christiansë (2009: 29)
\end{abstract}

Our debt to those who are already dead and those not yet born cannot be disentangled from who we are (Karen Barad, 2010: 266)

\section{BEGINNING WITH THE AMPERSAND}

\& alive\&kicking, dead\&gone, dolce\&gabbana, brandy\&coke, night\&day, down\&out. What intrigues is the way in which the sign's loop denies conjuncture; there is no possibility that the ends will meet. A powerful term nonetheless - this and is deployed consciously as yoke or hypothesis, or more usually, unthinkingly as a sloppy compound or conventional assumption: mr\&mrs, mother\&child. As someone who is sceptical of assumptions, and wary (like a nervous pony edging through acacia trees) of words, I tend to shy away from easy efforts to conjoin concepts with entities, to want examination of the political work done by an 'and', a 'but', an 'or'. As early as 1988, Elizabeth Spelman, a feminist philosopher, writes of 'the ampersand problem in feminist thought' (Spelman, 1988: 1). She explores some contemporary (white) US-based feminist debates' tendency to engage the challenges of 'gender and race' by using the 'and' to slough off the material and socio-cultural influences of racism in the lives of black women. The ampersand, she argues, allows white feminisms to imagine dynamics of exploitative 'gendering' potentially unlinked to 'race' (where there is an ampersand, there sits - semiotically permission to disconnect), and in the process to disappear the meaning of black women's historical and contemporary lives in feminist work (Spelman, 1988).

Spelman is surrounded, in this moment, by many other women of colour theorists in the North, simultaneously critiquing the discourses swiftly becoming known as 'second-wave feminism,' an appellation from its outset

${ }^{1}$ Head of Department (Gender Studies) and Deputy Dean (Staffing) in the Faculty of Humanities at the University of Cape Town, 
ignorant of (to adapt Paula Giddings's phrase) 'when and where [black women] enter' (Giddings, 1984). Her focus on the ampersand, however, as one of the linguistic technologies of collusion with analyses of gender that erase the centrality of race from theorisation, strikes me as a useful point of entry. I have spent most of my life, one way and another, attempting to come to grips with not simply 'genderandrace' but with another (allied) ampersand: gender \& violence. I am lucky enough both to have survived sexual violences, and much more importantly, to have worked for some thirty-five years amongst feminists and queer activists and writers who (in multiple forms of work) have tackled, with ferocity and enormous 'smarts', the normalisations of sexual assault in its myriad and ever-evolving shapes.

The complexity of the ampersand in 'gender and violence' cannot, however, be underestimated: does it gesture towards utter synchrony, or to a set of causes and effects? (Bennett, 2014). That complexity lives alongside another. Given the (for the most part) segregation of feminist debate from other theorisations of the socio-political issues, my thinking/being through tangles of gender\&violence also negotiates with both academic and popular epistemological trends. Once upon a time, one of these in the South African space was a robust Marxism; more recently, thinking about issues of socio-political justice has been galvanised by the concept of decoloniality as a framework for analysis and action. In terrains akin to those of my own research, such as environmental humanities, critical anthropology and psychology, the notion of the Anthropocene has become valuable in posing innovative questions about the meaning of 'being human' in a world traumatised not only by (overt and covert) war between peoples, but by inescapably geological, climatological, and 'non-human' damage. To imagine the ampersand of gender\&violence in the twenty-first century, I argue, is to fight for longstanding feminist insight into certain versions of trauma within the scope of debate that is willing to centre planetary damage in its theorisation of the past and the future (Barad, 2010).

In this article, I trace three different zones in which I have been inspired and tutored in the task of finding a language to theorise gender ' $\&$ ' violence. Although this is a life-task, my particular need to do this with integrity, and in conversation with other feminists, arises in a commitment to teaching about 'gender \& violence' in a national context with extremely high levels of gender-based violence and a contemporary context inflected by the legacies of colonial and apartheid violences. The article seeks to highlight concepts (theoretical, poetic, and spatial) that have offered me hope in thinking about whether it is possible pedagogically to engage representations of 'the disappeared': those enslaved, those whose humanity, systemic racisms and sexisms may have sought to erase, those at a distance and those closer to hand, some of whom work with me, as students.

The first section of the article begins with an exploration of recent discussions about the concept of the Anthropocene among some leading feminist writers, and notes the almost complete absence of deep engagement with experiences one might term 'rape'. I speculate a little about this occlusion, and then look for interlocutors who can help me understand how theories of 'a man-made epoch, and its exigencies' could more critically help me unpack my own dilemmas about the way the ampersand works to yoke the terms 'gender' and 'violence'. Because my work, or part of my work, is tethered to projects of teaching at a university in South Africa, I come at this dilemma practically. Which theoretical allies can I find to support ethical entry points into pedagogic design that recognises the critical vulnerability of the earth while simultaneously foregrounding forms of specifically gendered forms of violence: work that is vital to activist feminist strategies? Whose twenty-first-century voices seem capable of allowing me to 're-see,' re-listen with and to knowledges of (for example) rape, domestic violence, or sexual harassment whose roots extend back into decades of rich research, but which have not substantively shifted the grounds which require us to theorise these forms of violation: living within patriarchal worlds?

The second section chooses the work of a South African feminist critic, writer and poet, Yvette Christiansë, as opening one portal for rethinking an approach to languaging ethical recognition of the concerns raised by feminist writers on the Anthropocene, especially those taken up not only by recent conversations amongst Haraway (2015), Barad (2010), Colebrook (2017) and others, but also those raised earlier by the Jamaican theorist, Sylvia Wynter. Taking seriously Christiansë's work in Imprendehora (2009, at the University of Cape Town, collection of poems rooted in the possibility of hearing those 'liberated Africans' whose histories have been largely forgotten) allows us to argue that disappearance itself is never totalising. Close attunement to fragments of archive, imaginative insight, and genealogy may transform the concave impact of violence into legible, uncontainable, hopeful humanity.

Holding onto Christiansë's language, I then contextualise some of the dilemmas and the imaginative and intellectual conundrums involved in the design of a graduate seminar on Gender \& Violence that I have convened for several years. This is the third section, and argues that the work of designing a pathway for dedicated and invested communication ('teaching') summoned through the ampersand of 'gender' and 'violence' demands relationships with theorists and writers who trust feminism's fearlessness in the face of seemingly overwhelming erasure. 


\section{'THE RETURN OF “MAN”...?’(COLEBROOK, 2017: 5)}

After the notion of the Anthropocene as a geologically significant epoch received formal scientific recognition, in 2019, an article in the US magazine The Atlantic poured scorn on its hubris:

The idea of the Anthropocene is an interesting thought experiment. For those invested in the stratigraphic arcana of this infinitesimal moment in time, it serves as a useful catalog of our junk. But it can also serve to inflate humanity's legacy on an ever-churning planet that will quickly destroy—or conceal forever- even our most awesome creations. (Brannen 2019)

Through the narrow prism of a disciplinarily boundaried zone — geology — and surrounded by the paleoproterzoic rock formations of the Langeberg in the Western Cape, I have some sympathy for Peter Brannen's call-out. What, after Foucault's definitive 'death of man' (not to mention Aimé Césaire's call for a new and marvellous human being grounded not in colonial subjectivity but in the sources from which that man had alienated himself (Césaire, 1969)), does it mean to find ourselves negotiating an idea that re-inscribes, at its core, the mark of the human (writing the earth itself)?

The tension between two political (and philosophical) temptations animated by the notion of the 'Anthropocene' is difficult. On the one hand, we have the invitation to theorise planetary being as an assemblage (in the Deleuzian sense), metamorphosic influences in which the distinction between 'plant,' 'human,' 'stone,' and 'animal' dissolves and reconfigures in illuminating ways. On the other, the recognition of violence, located within 'human agency' (not in the agencies of stalagmite or fish), as the meaning of that agency (it is human violence which separates the Anthropocene from earlier eras) forces thought away from the pleasure of dissolving 'human' as category back into implacable wrestling with pain, damage, loss, and grief.

Feminist theorisations of 'the human' are integral to the core project of understanding the politics of genders and sexualities within the world as 'environment'. Ever since the late 1980s, some writers have worked tirelessly to centre the meaning of 'nature' as a gendered project, in which patriarchal and capitalist interests have feminised the environment as a route to its objectification and control. Sometimes corralled as 'ecofeminists', these writers can be grouped into different interests; Carol Adams and Josephine Donovan, for example, link violence against women to patriarchal abuse of animals, of 'nature,' and include pornography within the panoply of patriarchal weaponry (Adams and Donovan, 1995). Vandana Shiva and Maria Mies situate their ecofeminist theory much more centrally within a critique of capitalism, as 'maldevelopment' (Mies and Shiva, 1993: 132). Shiva is especially clear that colonially-driven capitalism deployed the Western gender binary in its organisation of 'export-oriented' agriculture in India and in much of Africa, and simultaneously confronts Western science as a form of knowledgemaking whose binaries split 'human' and 'nature' (animals and plant life) in ways that render the former 'rational' and the rest to be rendered meaningful under subjugation, a position shared by 'women-humans'. It is this critique of Western science as a critical weapon of patriarchal epistemology which forms the theoretical ground for later post-humanist feminist scholarship on the Anthropocene (Warren, 2009).

Assberg, in 2017, takes off on a feisty note with the recognition that an earlier generation of feminists had already deconstructed patriarchal deployment of the term 'nature': 'And it (feminist posthumanism) presents a Riot Girl/ Tank Girl type of sly smile to moralistic statements such as “it's not natural." It never was, we never were. Now what?" (Åsberg, 2017: 187, original emphasis). She synthesises discussions among contemporary Northern feminists on the recognition of the posthuman as a theoretical notion from which to tackle the anthropocenic claim of 'human' as constitutive of 'nature'. Noting Barad's interest in 'posthuman performativity' (Barad, 2010: 176) as a route to explore the disappearance of any fixed separation between 'human' and 'non-human' and simultaneously invoking both Haraway's 'combustive precursor figure', the cyborg (Åsberg, 2017: 187), and Halberstam and Livingston's (1995) conviction that any vestigial faith in the concept of a singular 'human' had been eradicated within the recognition of the transformative simultaneities of queer, alien, and human, Åsberg concludes:

(...) in all its variety, feminist posthumanities (...) encircle a postdisciplinary premise on which to rethink human nature, and consequently in the Anthropocene context practice the humanities, otherwise. (Åsberg, 2017: 200, original emphasis)

An ordinary issue is missing from this lexically somewhat overburdened argument: while we puzzle, polysyllabically, at the blur of a binary (human/non-human), is there any value in retaining critique of the term 'man?' For the ecofeminists of the 1970s and 1980s (whose work continues in multiple forms of activism and research), 'man' connoted those upon whom Western scientific patriarchy conferred rationality, the right to control in the best interests of a 'universal humanity', and access to 'women's' bodies. The debates of posthumanist feminism are less interested in the meanings of 'man' and 'woman', and concentrate more deeply on what it means to think 'the earth' beyond a preoccupation with human being. 
A key influence on my thinking comes from Sylvia Wynter, who has since the 1970s worked at, and with, the imperative to reimagine 'knowledge', after what she terms the 'over-representation' of Man is exposed as merely the symbolic deployment of liberal humanism. Wynter argues that the descriptive statement which writes 'Man' involves his fundamentally flawed constitution as human (Wynter, 2000). In many pieces, she unravels the fragile configuration of Western patriarchal and religious discourse in imagining a Man, whose 'other' functions as projective space for those enslaved, colonised, exploited, and 'de-humanised.' In a review of a collection of essays inspired by Wynter's work, edited by Katherine McKittrick, Rodriguez reminds us that Wynter's roots are Jamaican, and as a radical Black intellectual, she writes to 'reinterpret the history of the modern world from the perspective of the plantation system of the ex-slave archipelago of the Americas' (Rodriguez, 2015: 8). Wynter's call reminds us not to lose our suspicious attunement to the term 'man' which simultaneously demands that we never forget his political agenda even as we commit to debates which arise from his irrelevance.

Wynter's and Rodriguez's starting with the 'plantation' holds my attention. In 2014, the Centre for TwentyFirst-Century Studies at the University of Wisconsin-Milwaukee convened a colloquium of feminist scholars to work together at the opportunity offered by the concept of the Anthropocene: 'What does feminism have to say about the Anthropocene? [and] how does the concept of the Anthropocene impact feminism?' (Grusin, 2017: 4). Haraway's early theorisation of the interlock between life named as 'human', the technological, the natural and the social undergirds the essays of the eight authors whose writing comes together in Anthropocene Feminism (Haraway, 1985). Their approaches range widely, but all reject the idea that 'human' as a climatological force carries any salience except in terms of an invitation to re-engage science in the name of what Braidotti calls 'zoë-'conscious recognition of the imperative to decentre humanism (Braidotti, 2017).

Braidotti's demand to centre the dynamics, and value, of ₹oë (life-force) rehearses Buddhist ideas of sentient being and she urges feminism to welcome the wrestle with 'philosophies of radical immanence, vital materialism, and the feminist politics of locations' (2017: 45, emphasis added). A year after this colloquium and others with similar agendas, Haraway published a piece in Environmental Humanities in which she suggests that scholarship that decentres the human must recognise the conditions under which notions of the organic or the non-human have become indistinguishable from processes of capital and extractivism. In a footnote to her article playing with power of reification, 'Anthropocene, Capitalocene, Plantationocene, Chthulucene: The making of Kin,' she explains:

[T] he participants collectively generated the name Plantationocene for the devastating transformation of diverse kinds of human-tended farms, pastures, and forests into extractive and enclosed plantations, relying on slave labor and other forms of exploited, alienated, and usually spatially transported labor. (Haraway, 2015: 1616)

In the Ethnos piece that also explores the conversation of these participants, the texture of the discussion is glossed:

Noboru (Ishikawa): To me, plantations are just the slavery of plants.

Anna (Tsing) - I agree.

Donna (Haraway) —And microbes. (Haraway, 2015)

As Davis et al. (2019: 5) point out: 'Human labor [sic] receives brief attention'.

I find something deeply disturbing in scholarship that claims its roots in feminism that can describe plantations as 'just the slavery of plants'. If the Anthropocene functions as an invitation to push the envelope of what can be understood or imagined (chthulucenic — past/present/futures) as earth, when and how did terrains of labour, through which millions became enslaved and racialised as 'outside the human' become about plants? It could be argued that I was wilfully misunderstanding, that in Haraway's deep sea-diving to discover possible language, she is as alert to the histories of race and racism as is critical, that in this piece stimulated by riffs around the Anthropocene, she is simply 'doing something else for the time being.' I am not sure; I read the work, a few years after it was published, and alongside Davis et al., I am uneasy: how is it possible to have a 'feminist' conversation with the Anthropocene, where the work of decentring its claim to Cenozoic salience for 'the human' disappears the humans captured on plantations?

The way Davis et al., respond is with a review of philosophical and (broadly) sociological work debates on the notion of the Anthropocene, which centre questions of colonialism, race, and in particular, slavery. Invoking Vergès (2015), who writes of the 'racial Capitalocene' as a way of thinking through plantation-processes as simultaneously human and organic/plant-centred, the authors note:

(...) dissatisf(action) with theorizations of the Plantationocene that minimize the ways in which racial politics structure plantation life (both human and nonhuman). Such approaches limit a more nuanced and grounded understanding of the ways that the plantation inflicts socioecological violence as it simultaneously prompts differentiated, multifaceted, and relational ways of being. (Davis et al., 2019; 15) 
So I find myself wanting to park Haraway, a brilliant scholar from whom I learn, as I try for engagement with the options opened by feminist theory to recalibrate the influence of the 'human' towards what Barad terms 'the hauntological': 'the thing that represents the demise of something also signals its continuation in a different form' (Barad, 2010: 276). Haraway's 'Chthulucene' desires a holographic vision of earth as 'past, present, and to come' (Haraway, 2015: 34), a version of 'compost' from which re-worlding could be imagined. A feminist discussion, sparked by the popularity of the concept, cannot be content with historical claims to feminist indictment of human (men's) environmental brutalities (such as offered by the earlier work of Vandana Shiva) nor with new theoretical horizons around the language of possible being. A feminist discussion has to start, following Wynter perhaps, with an exploration of human violence which 're-appears' the meaning of the disappeared, a meaning capable of holding the slavery of people in a move that will also embrace the slavery of plants.

\title{
'THIS IS THE SOUND OF A HORIZON HELD OPEN/WHEN A BODY IS LAID DOWN'(CHRISTIANSË, 2009: 26)
}

Yvette Christiansë, a black feminist poet and theorist, wrote her first collection of poetry, Castaway, in 1999, and introduced me to language that was capable of ascension, by which I mean language that is supple, fragile, bitter, and strong-willed enough to conjure living bodies from the dead, especially the violently disappeared dead, those barely known, numbers and names in a ledger, or those dear to one family, alone, one grandmother's enslaved ancestry. The collation of poems trace, through fragments, the spool of reclamation urged by the life of 'Finnie,' Christiansë's grandmother. 'Finnie's' people are those who were, after Britain's Abolition Act of 1807, 'liberated' from slavery into historical and physical limbo (and continued brutality) in settings as diverse as the Seychelles, Brazil, Cuba, and the island of St Helena. Christiansë writes of the collection that its creation deliberately argues with history: 'this argument was staged in personal terms in that I had wanted to bring to the fore a voice for which there is no discursive place in any formal history' (Christiansë, 2006: 303). This voice (her grandmother's) is never offered speech across the collation of discarded hints of lives, images, sounds of St Helena, so that she ('Finnie') escapes any appropriation and yet signifies as umbilical $\mathrm{c}(\mathrm{h})$ ord for the poet herself.

In my search for a language capable of summoning violent disappearance, in the crucible of the expansion of Anthropocene to Plantationocene, I turn to Christiansë for two reasons. Firstly, I am captured by Avital Ronell's evocation of poetic work: 'poetic courage consists in embracing the terrible lassitude of mind's enfeeblement' (Ronell, 2014: 6), where courage wraps around the incapacities of the intellectual to glimpse another path. Secondly, in reading Christiansë, I am offered a geographical route — as she writes an imagery of a 'return' (from enslavement, to the island, to herself, born at the tip of Africa), perhaps I can hold on, after listening to Northern feminist visionaries, and find my way back to my beleaguered home.

Christiansë's second collection, Imprendehora, ten years later, in 2009, is named for one of the ships that carried people into slavery. It was apprehended en route, and the figures in the hold were taken to St Helena, to be indentured, rendered 'free' of slavery into nowhere, a tiny island, shackled not by irons, but, primarily, by asemia. Cartographically held (as in a cupped palm) by the Atlantic and the Indian, and collated through epitaphs of the transitional ('Scraps,' 'Winds,' 'Rust'), the poems summon time, water, insects, stone, bodies living and not, and foliage as avatars. The collection opens through the (perhaps) whispering (the font is italicised) of a 'Liberated African woman, who had the night previous, hung herself to the tree in Rupert's Valley' (Christiansë, 2009: 9) (and, perhaps it is her voice; perhaps it is a voice simply in juxtaposition with that newspaper account): 'a spider pulling stone together makes/ more noise than a spirit leaving a body' (Christiansë, 2009: 9). What does the spirit leaving the body sound like: 'the spider spinning its web goes carefully/ around the moon caught swinging in a tree' (Christiansë, 2009: 9). Who swung in the tree? How will the spider dare, tiny movements, alert to disaster?

The poems begin to spin, titles alone carefully tracing co-ordinates: 'abundance,' 'the lives we lose,' 'caught', 'in this place', 'there is no rest', 'no rest at all', 'rocks and stones'. Acutely sensitive to lurking violation, 'The laughter of birds can break a knuckle', and to the way being of/on earth hurts, 'The boughs of trees/ some say, chafe most', the poems (I work here with those in the first theme, entitled 'Scraps') interrogate the already-said, and directly address assumptions of the anthropomorphic:

\author{
Do not liken the wind \\ To our inhalations and exhalations \\ Do not say the sound of the ocean \\ is the ocean whispering \\ Or shouting our names' \\ ('The Shattering of the Vessels', Christiansë, 2009: 40)
}


Christiansë's language here (refusing a 'tilted world,' the one in which black women's bodies, reported as 'felo-de-se' [killing of the self], appear as news items) insists on distupting familiar relations (metaphoric or otherwise) between the human and the environment. As 'the shattering the vessels' is summoned-an energy beyond the anthropomorphic or panoptic - voices are lucid: 'we have been waiting for her/ we have been singing her name/ here in the tall branches' (Christiansë, 2009: 40). In the branches, which allowed one woman to transition from death to spiritual immanence, we hear the song of an invitation to re-worlding which can, 'carefully', honour the (black)(disappeared)(woman's) philosophical power.

The final poem in the collection speaks with some of the names in a register, documenting the arrival of men and women 'released' from slavery by a British ship, the Columbine, policing slavery in 'Katembe' (the seas named as the Indian Ocean), in the early 1800s onto the shores of the Seychelles. In an interview with Shaun de Waal in 2009, Christiansë is reported to have said, 'I was so shocked, so moved by that register, (...) the horrors of what it meant to be a "liberated African". The ironies of that name' (2009). The poem's grasp of 'shock' surges into the bare registry identifications ('345 Male Samuel. Age 4. Stature 3-3/Mother's name Neammhoo? Neammorhoo?') (Christiansë, 2009: 83) to blast away at the calligraphic pinning-to-paper of holographically complex, emotional, and fragile life:

'They have no idea/ who I am, and who I am/ is a parcel I keep/ tight in my throat/ like seeds in many layers/ against bad weather' (Christiansë, 2009: 87).

I would be honoured to write more deeply about Christiansë's intense poetic integrity as the writing insists that language can access genealogies of the disappeared, and that a shattered world is not not-a-world. Here, though, a small reflection on Imprendehora facilitates a closer relationship to Wynter's insistence that the politics of race must infuse any representation of modes of being, against and beyond 'Man'. It allows me to think more deeply than binaries, and to trust that what cannot be discerned (save disappearance, save scraps, save wind) may nonetheless both demand attention and permit an epistemic pathway into language. While the notion of the Anthropocene gives new language to feminist wrestling with the violences of 'man,' Christiansë's poetry suggests how to trace Haraway's 'Chthulucene': the world past/present/to come.

\section{SPEAKING OF GENDER \& VIOLENCE}

The final section of the article returns to its animating question: how to understand the ampersand in 'gender \& violence,' so that contemporary and historical contexts in which this ampersand becomes generative are not too overwhelming for speech. It seems to me ethically essential that to stimulate knowledge-sharing entails a commitment to a future, to a version of a horizon, to possibility. For the past few years, in my formal location in the School of African and Gender Studies, Anthropology and Linguistics at the University of Cape Town, I have designed a curriculum for postgraduate students entitled 'Gender and Violence.' It's an elective course, and offered an opportunity to 'think,' in an environment (mostly) free of any immediate crisis of physical, sexual or emotional assault (far away from the norms of South African streets, homes, institutions, bars, religious spaces, sports arenas, or plain old post offices). Most syllabi in 'gender studies' - the transdisciplinary terrain in which I am placed ignore sustained engagement, say over months, with the fact that what is called 'gender-based violence' constitutes a ubiquitous and living pulse of toxic surveillance. I am currently researching whether this could be multidetermined. The terrain is demanding in and of itself, and requires engagement with questions of the economy, politics, cultural studies, and history inter alia. Where and how to situate 'violence' here is a taxing issue. Perhaps more importantly, 'gender studies' works extremely hard at the edges of theorisation of and contribution to activism that seeks to shift the grounds on which the politics of gender and sexualities construct injustice. So, 'we' spend a lot of time with questions of power and organisation, of strategy, of emotion (joy, anger, fear), and of healing (in different forms: epistemic, but also social/individual). In addition, in any one zone, there are likely to be very few 'gender studies professors,' who don't have our own battles to wage against attacks on our intellectual, and political, credibility.

The necessity of a serious opportunity for young postgraduates to think, and write, about 'gender \& violence' arose from two imperatives. The first was the intensity of experiences in which being 'gendered' had led to being violated, in the room (so to speak); in work that attempts to 'walk the talk,' side-lining these experiences as zones of theory constituted stupidity. Secondly, and as the above sections have suggested, the era in which I have worked from the 1980s until the early twentieth century has seen rigorous black feminist theory on the rejection of Man (pace Wynter, and in interlocution with others), and simultaneously a sweeping rise in the recognition of human violences whose effects 're-work' the earth: the Anthropocene. I believe that twenty-first-century 'teaching' (in tiny, alienated, university-bound rooms) has to support the work of thinking about violence, and for me, I began in an obvious way: gender and violence. 
What I want to reflect upon here is not the ways in which he course (offered from 2012 on, in changing forms) was realised live. The actual dynamics (physical, aural, textual and psychological) which flow between approximately 24 very diverse people, whose only contract with one another at that hour, in that space, involves agendas whose roots are too fragile to map, are indescribable. I will not try, here, to invoke them. Instead, I explore the questions that arose for me as I choreographed (perhaps too ambitious a word) a curriculum, which would allow safe-enough, collective, out-loud (and not out-loud) thinking about the ampersand. In which ways could the juxtaposition of those terms conjure the recognition of power? How was it possible to represent such juxtaposition? What forms of strategic energy could flow from an interrogation that we knew what we were talking about when we said, 'rape,' 'extractivism,' or 'transgender justice'? How could contemporary language on the Anthropocene revision 'humanity'? What voices are able to give texture to serious intellectual work that refuses the potentially totalising impact of man-made violence? How was it possible to hope?

\section{'STAYING WITH THE TROUBLE'(HARAWAY, 2016)}

The first problem to be introduced is of course the one epistemologically lodged into an understanding of 'gender.' For decades, rooted in a liberal feminism, 'gender' evoked a politico-social force that thrived on categorisation according to a binary: 'man'/ 'woman.' In the name of this approach, some important work on ideas of 'equality' and 'equity' occurred, especially linked to ideas about party-political representation of people in various hierarchical tiers of government (Hassim, 2006. In some circles, the notion of 'gender' as primarily responsible for an individuated legal, and familial, subject nominalised as 'woman' galvanised poetry, policy, and interrogation of consciousness itself. There was never a moment, within the development of this idea of 'woman' unchallenged by its homogenisation, and wherever the singularising term found traction (often, in African contexts, in postindependence legal reform movements strongly influenced by notions of Western subjectivity in their debates on 'new' rights), challenges arose about the deployment of a concept which seemed immune to questions of difference. Many challenges, especially in the United States of America and South Africa, drew on the recognition of racialisation and racism to point out the fragility of 'woman' as any all-compassing version of an oppressed constituency (Moraga and Anzaldúa, 1983; Hill Collins, 1990; Lewis, 1991). This, in turn, I argue, led to a consistent tension in South Africa between scholars who use additive listings ('gender, race, class, sexuality, and...' following a Bill of Rights grammar) and scholars who advocate for less liberal discernment of the fluidity and menace of power deployed against the interests of being. 'Intersectionality' became popular as an idea which could do this work, especially in the name of colonially-based racism, attracting radical rejection of the ways in which liberal notions of 'womanhood' were useful. When it comes to 'gender and violence,' however, demands for intersectionality as political theory capable of narrating embodied violence has not been strong enough to displace a by now deeply rooted connection between 'gender' and 'violence.' That connection is causal, and assumes that a binary allocates roles and vulnerabilities. 'And' confers distance between the terms, where 'violence' is primarily caused for 'women' by 'men', through the conditions of their mutual being/becoming gendered. \#MenAreTrash, a hashtag which emerged on Twitter and Facebook in 2016 as a rallying call against rape gets inflected by race/class in much social media and academic discourse, but still, \#MenAreTrash remains a popular, dichotomizing, call.

How does such a use of the ampersand (a use which has effected enormous change in what it is possible to know concerning sexual violence and harassment) sit alongside another reading? Attunement to queer interrogations of 'gender', arising from different contexts, locates the process of gendering not simply as a politics but essentially AS a violence. In the Preface to Reclaiming Afrikan, Zethu Matebeni glosses both Butler's "'queer" as the present never fully owned' (Butler, 1993: 49) and Halberstam and Livingston's desire to wrestle queer theory away from white-dominated Northern debates (Halberstam and Livingston, 2014), as they claim the ' $\mathrm{K}$ ' in Afrika as the sign of their own erasure, in African contexts, about the meaning of being human. The violence of continual deletion as 'human' - 'that you can be both seen and unseen is private and in public spaces is central to queer' (Matebeni and Pereira, 2014: 4) — is embedded in the concept of gender itself as a route towards recognition as human being. Here, the ampersand becomes the copula: gender is violence.

\section{'RAPE IS A LANGUAGE’(GQOLA, 2015: 17)}

If the first problem for someone thinking through the gender $\&$ violence ampersand, as a route to conversations about Man, the earth, and humanity, is the logical capriciousness of the sign (signalling 'flow'/signalling 'essence'), the second is even more slippery. 'Es la desaparicion; Es la violación' - 'it's disappearance, it's rape' — are the lines chanted in a wildly popular protest feminist performance about sexual violence, originating in Chile in 2019, and spreading rapidly for months throughout the world (it was chanted in Kolkata, in early 2020 protests calling out the government's violations of women's rights; it was chanted in New York, outside Harvey Weinstein's trial, in 
February 2020). The discursive conundrum facing autobiographical narratives of experiences in which the \& is implicated (say, in one logic: the rape of a woman; say in another: the public humiliation of a transgender person) is oxymoronic. To be a plausible narrator (one whose tale can be tolerated as 'likely'), you have to be pre-scripted into a version of innocence as human in order to be credible (Gqola, 2015). It is extremely difficult simultaneously to tell an autobiographical narrative of being raped and retain credibility: the experience itself (that you were careless or ill-attuned enough to have 'it' happen to you) is enough to strip you of your credibility. The wariness with which the sentence, 'I have been raped,' is described as much in studies of police officers' responses to the request to lay a charge (Smythe, 2015) as in the assumption that someone who has experienced rape can — and should — be deeply heard only by those trained to do this: counsellors, healers, psychologists. A question I frequently ask in training workshops I run (with others) on strategising against rape is: 'What happens for you when a friend tells you they have been raped?'. Responses acknowledge the moments of 'freeze,' of the sense that their interlocutor has introduced material which forms an immediate barrier between the two of them, which requires arduous and intricate engagement; the friend has, momentarily, moved 'outside' familiarity and the fiction of easy communication.

In thinking about the logic of the $\&$ in gender\&violence, the first challenge was to accommodate algorithms which do not align with one another. The second is the strength of hegemonic discourses, in which questions of gender interlaced with the meaning of violence arise, and are capable of the erasure of the ' $\mathrm{I}$ ' as 'survivor'. These challenges make extraordinary demands on anyone who believes that violence, 'humanised,' experienced as a form of obliteration by many, skewered through the malevolence of gender/race, requires address, and, indeed, pedagogically oriented address, address formal and serious enough to offer a qualification as a scholar.

Holding firmly onto Christiansë's 'O' at the centre of 'Finnie's' mouth, in Castaway (Christiansë, 1999), and with Wynter's encouragement to centre responsibility for the disappearance of people at the feet of race-based capitalism (Wynter, 2000), I refused to give up my quest to 'teach' the ampersand, as a feminist, within a world ravaged by human extractivisms.

\section{'UNCERTAINTY, UNRESOL VABLE NARRATIVES, AND CONTRADICTION' (FUENTES, 2016: 12)}

Marisa Fuentes, feminist historiographer, published Dispossessed Lives: Enslaved women, violence and the archive, in 2016. It is a book which refuses to settle with the absences in the colonial archives of Barbados, one of the Caribbean islands, heavily populated by both enslaved and 'freed' black women, in the eighteenth century. Her dilemma resonated (at an angle) for me with my own (and is the starting point for much black and decolonial theory): what is the work of reading the disappeared? Fuentes begins the book with a colonial relic: an advertisement promising reward for the return of a woman ('Jane') who had escaped her slavery, who is 'short,' and whose body bears the scars of branding and beating. There is no more available text about 'Jane,' and Fuentes turns her mind, and all her senses, to a tentative, imagined-yet-possible, representation of a late eighteenth-century Bridgetown in order to discover 'the fugitive.' Reading against the grain of other colonial fragments concerning different enslaved women's stories, working with maps of eighteenth-century Bridgewater and logs of shipping vessels coming in and out of the port, permitting the possibility of sound and smell to infuse the experience someone 'lost' off the record, Fuentes weaves in and out of record, analogy, representations of space, and imagination to suggest a fleeing figure: 'walking along the careenage, Jane would smell the seawater, mixed with the sour and dank smell of too many people in too small an area' (Fuentes, 2016: 25).

Taking guidance from Fuentes' attention to what-can-still-be-seen, I find a way to begin.

The university in which I teach is situated in Cape Town, South Africa, whose growth as a city is completely embedded in narratives of enslaved people, trafficked into what began as a small settlement, from 1658 onwards under the auspices of the Dutch East India Company. The majority came from families in Indonesia, Madagascar, India, Mozambique and South-East Asia. The city itself, in 2020, is readily recognisable as having been built around the project of development through enslaved people's labour: aside from the physical ruins of the dominating seventeenth-century Dutch-affiliated Castle and the physical layout of the central city, Cape Town is home to over five million people who can trace direct genealogical routes into enslaved ancestry. Language, cuisine, and religion (Islam, in particular) colour the environment with the memory of enslavement in ways that define the city, but as scholars such as Worden and South point out, the 1994 transition to 'democracy' did not take this heritage seriously as a route towards re-naming, memorialising and re-thinking the urban space (Worden, 2009; North, 2017). It took the concerted activism of small political groups to begin shifting the meaning of public pre-1994 histories to include (and be challenged by) the nearly three centuries of intersections between land, agriculture, labour and enslavement at the Cape.

A decision was made to contribute to the recognition of slavery as fundamental to African historiography at the Cape, by transforming one of the oldest buildings (erected in 1697) in the city centre into a museum, to be 
dedicated to holding the enslaved in the present. The building, now known as the 'Slave Lodge' and managed by the Iziko group of museums, attempts to transform a site designed originally to house enslaved people (which later became a government office, a post office, and even for a while a Supreme Court) into a place which can evoke and teach. In 2020, it remains a strange, disconnected hodge-podge of artefacts, installations, art pieces, and visual materials, attempting to remind the viewer both of the global scale of (ongoing) slaveries and of the specifics of Cape-located lives: a shackle, an ancient anchor, and — almost unbelievably — images of gravestone plates of Jan van Riebeeck and his wife. North describes the museum as 'a space that aims to portray a range of South African human rights abuses, and depict a nation that has overcome a challenging past. In this sense, the discourse of national reconciliation' (North, 2017: 213) and although he notes that the museum's limitations are both frustrating and well-known to Iziko staff, it is worth noting that the most recent addition to the museum is dedicated to the reclamation of the San Joae, a drowned slaving vessel, discovered in 2015.

The problematic of the 'Slave Lodge' holds, for me, the themes that confound the gender\&violence ampersand: the impossibility of representation, the wrestle between 'slavery is violence' and 'those enslaved became subjected to a vast range of violences, arising from the processes of slavery'; and the need to work epistemologically from the recognition of the disappeared. It holds, too, a physical insistence on the notion of the enslaved people's labour (the Plantationocene?) as inextricable/inextractible from questions on the formations of the earth.

The heart of the curriculum design for 'Gender And Violence' lies with the mess of the Iziko 'Slave Lodge;' outside the university's walls, in a space where we are invited as learners, but enter (often) as great-great-great grandchildren, strangers, awkwardly intergenerational, carrying 'IDs' (as university members) which wrench us all into fake liberal uniformity. Before we visit, we read about the archive, the challenge of 'curating the disappeared,' and we discuss Fuentes's conviction that we are not severed from the past, despite its trauma and despite the attraction of amnesia for some (my classes hold people with diverse backgrounds, and they hold me, too).

Given the minute care taken by the Dutch East India Company (the VOC) to document the processes of human, administrative and trade flows around the Cape, the colonial archives (also in the middle of the city) stretch back to 1651 (a letter from Jan van Riebeeck), and comprise millions of pages. There is no archival record of written records created by those who were enslaved, and several feminist historians have explored women 'slaves" lives through what Yvette Abrahams in 'Was Eva Raped?' calls 'speculative' work (Abrahams, 1996: 4) and Gabeba Baderoon suggests as the 'ambiguous visibility' of the contemporary researcher (Baderoon, 2009). There is something completely astonishing (to a feminist) in the curation of the 'Slave Lodge'. For many decades, as is noted by Worden (2009), and the Museum's own website, the lodge was open, for several hours every night, as a 'brothel,' or - more accurately — as a house of acceptable sexual assault. Enslaved women (a least one of whom, the website is quick to note, had chosen sexual liaisons with the men who visited) were forced to experience what can only be described as regular rape. There is nowhere in the lodge itself, where this all-defining reality is memorialised as serious and at the core of what it must have meant for enslaved women. In 2018, the Sex Workers Education and Advocacy taskforce (SWEAT), an NGO in Cape Town, supported an advocacy-installation ('I am what I am,' created by Lynn Adams) in the entrance hall of the lodge, but that lasted for only a few weeks.

Shattering as this is, an invitation to 'see' enslavement while obscuring rape signifies powerfully for me that gap in the ampersand: gender $\boldsymbol{\&}$ violence. The sign suggesting conjuncture hints, instead, if traced attentively, to the idea that the ends don't meet: they cannot meet as currently configured. Unless, and until, the representation of black women's experiences - enslaved, on plantations, on Cape farms, in motherhood, under sexual assault, as simultaneously everything (the resource for ensuring life, which includes joy, and livelihoods, which include organic growth) and nothing (the disappeared) — informs all theorisation (Chthulucenically), there can be no hint of humanity.

\section{CONCLUSION}

Theorisation of being through the anthropocenic gaze invites us to recognise that the shape of the earth constitutes always a profoundly micro-political relation to the discernment of 'human' and 'non-human'. We (as 'human') can see only the most limited profiles of 'the earth,' given our highly differentiated, silo-informed, and frequently self-centred epistemological options. While, within middle-class circuits of access to 'information, it is possible to be bombarded by 'facts about the earth' coloured by panopticon hubris, the reality is that access to deep and complex languages around the meaning of 'being human,' rooted as we are, in and with 'earth,' is extremely challenging.

One of the areas in which I have found this to be most true comes from a lifelong engagement with the effort to grasp the meaning of the ampersand in the phrase 'gender \& violence.' One challenge arises in the exploration of the meaning of the term 'violence' for beginning to grasp the impact of anthropocenic economies: the temptation is to re-invoke the term 'rape' to describe the ways in which extravisms currently radically damage and traumatise natural and material synergies (air, water, 'non-human' growth and fertilities). 
In this article, I have tried to hold myself accountable to the silences I have found within many contemporary Northern feminist responses to what the critiques of the notion of the Anthropocene can offer theorisation of violence. These silences strike me as critically involved with the violences experienced by those 'disappeared' within the growth of capitalism: enslaved people, black people, black women. I may exaggerate the scale of this occlusion, but I found it resonant enough to turn through the work of Sylvia Wynter to the poetry of Yvette Christiansë in a search for an ethical language in term to speak about gender and violence with young, (often) South African students.

Curriculum design constitutes a form of 'theorywork' which is frequently invisible within the parameters of 'research.' I would argue, nonetheless, that the design insists on finding ethical relationships with a panoply of feminist thinkers, in differing genres (where poetry is as much of a resource as formal theory), and a starting point which one can trust to link ancestry to contemporary context, and to hold grief, rage, and vision together. This is especially the case when the interlocutors with which one shares a design, as a map for new languages, are young, brilliant in maverick ways, mostly dispossessed of land (they are black South Africans), and often survivors of sexual violence. Feminist engagements with the notion of the Anthropocene have pulled us into futures where recognition of the earth's vulnerability must be assumed as critical. At the same time, the ampersand linking 'gender' to 'violence', in myriad and often conflictual ways, does not allow language rooted only in the 'posthuman.' This article suggests that Wynter's suspicion of 'man' remains valuable, that Christiansë's evocations of fragmented embodiment as knowledge implacably centre enslaved black women's theories on violence, and that this helps me block a stage from which I am sufficiently, although anxious, willing to try for speech.

\section{REFERENCES}

Abrahams, Y. (1996). Was Eva Raped? An Exercise in Speculative History. Kronos: Journal of Cape History, 23, 1318.

Adams, C. and Donovan, J. (eds) (1995). Animals and Women: Feminist theoretical explorations. Durham, NC: Duke University Press. https:/ / doi.org/10.1215/9780822381952

Åsberg, C. (2017). Feminist Posthumanities in the Anthropocene. Journal of Posthuman Studies, 1(2), 185-200. https://doi.org/10.5325/jpoststud.1.2.0185

Baderoon, G. (2009). The African Oceans - Tracing the Sea as Memory of Slavery in South African Literature and Culture. Research in African Literatures, 40(4), 89-107. https://doi.org/10.2979/RAL.2009.40.4.89

Barad, K. (2010). Quantum Entanglements and Hauntological Relations of Inheritance: Dis/continuities, Spacetime Enfoldings, and Justice-to-Come. Derrida Today, 3(2), 240-268. https://doi.org/10.3366/drt.2010.0206

Bennett, J. (2014). Circles and Circles: Notes on African Feminist Debates Around Gender and Violence in the c21. Feminist Africa, 11, 21-47.

Braidotti, R. (2017). Four Theses on Posthumanist Feminism, in R. Grusin (ed), Anthropocene Feminism, (pp. 22-42). Minneapolis and London: University of Minnesota Press.

Brannen, P. (2019). The Anthropocene is a Joke, The Atlantic, 13 August. Available at: https:/ /www.theatlantic.com/science/archive/2019/08/arrogance-anthropocene/595795/). (Accessed 5 May 2020).

Butler, J. (1993). Bodies that Matter: On the discursive limits of 'sex'. New York: Routledge.

Césaire, A. (1969). Une Tempête. Paris: Seuil. https://doi.org/10.3917/presa.067.0003

Christiansë, Y. (1999). Castaway. Durham, NC: Duke University Press. https://doi.org/10.1215/9780822396208

Christiansë, Y. (2006). Selections from Castaways, in S. Pierce and A. Rao, Discipline of the Other: Correction, corporeality, colonialism (pp. 303-315). Durham: University of Duke Press. https://doi.org/10.1215/9780822387930-011

Christiansë, Y. (2009). Imprendehora. Cape Town: Kwela Books/Snail Press.

Colebrook, C. (2017). We have always been Post-Anthropocene: The Anthropocene Counter-Factual, in R. Grusin (ed), Anthropocene Feminism (pp. 1-21). Minneapolis and London: University of Minnesota Press.

Davis, J., Moulton, A., van Sant, L., and Williams, B. (2019). Anthropocene, Capitalocene, Plantationocene? A Manifesto for Ecological Justice in an Age of Global Crises. Geography Compass, (13)5, 1-15. https://doi.org/10.1111/gec3.12438

Fuentes, M. (2016). Dispossessed Lives: Enslaved women, violence and the archive. Philadelphia: University of Pennsylvania Press. https://doi.org/10.9783/9780812293005

Giddings, P. (1984). When and Where I Enter: The impact of black women on race and sex in America. New York: William Morrow.

Gqola, P. (2015). Rape: A South African nightmare. Johannesburg: Jacana Media.

Grusin, R. (2017). Anthropocene Feminism: An Experiment in Collective Theorizing, in R. Grusin (ed), Anthropocene Feminism (pp. vii-xx). Minneapolis and London: University of Minnesota Press.

$10 / 11$

(C) 2021 by Author/s 
Halberstam, J., and Livingston, I. (1995). Posthuman Bodies. Bloomington: Indiana University Press.

Haraway, D. (1991) A Cyborg Manifesto: Science, Technology and Socialist Feminism in the Late Twentieth Century, in D. Haraway (ed). Simians, Cyborgs and Women: The Re-invention of nature (pp. 149-181). New York: Routledge.

Haraway, D. (2015). Anthropocene, Capitalocene, Plantationocene, Chthulucene: Making Kin. Environmental Humanities, 6(1), 159-165. https://doi.org/10.1215/22011919-3615934

Haraway, D. (2016) Staying with the Trouble. Durham, North Carolina, Duke University Press. https://doi.org/10.1515/9780822373780

Haraway, D., Ishikawa, N., Gilbert, S. F., Olwig, K., Tsing, A. L., and Bubandt, N. (2015). Anthropologists are Talking-About the Anthropocene. Ethnos, 81(3), 535-564. https://doi.org/10.1080/00141844.2015.1105838

Hassim, S. (2006) Women's Organizing and Democracy in South Africa: Contesting authority. Madison: University of Wisconsin Press

Hill Collins, P. (1990). Black Feminist Thought: Knowledge, consciousness and the politics of empowerment. London: Harper Collins.

Lewis, D. (1991). Myths of motherhood and Power: Reflections on 'Black Woman' in Literature. Unpublished Paper presented at 'Women and Gender in Southern Africa' Conference. Durban, South Africa.

Matebeni, Z. and J. Pereira, (2014) Introduction, in Z. Matebeni (ed), Reclaiming Afrikan: Queer perspectives on sexual and gender identities. Cape Town: Modjaji Press.

McKittrick, K. (ed). (2014). Sylvia Wynter: On being human as praxis. Durham, NC: Duke University Press. https:// doi.org/10.1215/9780822375852

Mies, M. and Shiva, V. (1993). Ecofeminism: Critique, influence, change. London: Zed Books. https://doi.org/10.5040/9781350219786

Moraga, C. and G. Anzaldúa (eds). (1983). This Bridge Called My Back: Writings by radical women of color. New York: Persephone.

North, S. (2017). Museums as Tools for Understanding Slavery and its Legacies in South Africa. South African Historical Journal, 69(1), 82-100. https:/ / doi.org/10.1080/02582473.2017.1297480

Rodriguez, A. B. (2015) Book review: On Being Human and Praxis. Antipode, Sept, 1-8.

Ronell, A. (2014) Stupidity. Champaign, IL: University of Illinois Press.

Shiva, V. (1988). Staying Alive. Women, ecology and development. New York: South End Press.

Smythe, D. (2015). Rape Unresolved: Policing sexual offences. Cape Town: University of Cape Town Press.

Spelman, E. (1988). Gender and Race: The Ampersand Problem in Feminist Thought, in E. Spelman (ed), Inessential Woman, (pp. 23-47). Boston: Beacon Press.

Vergès, F. (2015), Cartographies of Memory, Politics of Emancipation, in N. Frith and K. Hodgson, At the Limits of Memory: Legacies of slavery in the francophone world (pp. 205-229). Oxford, Oxford University Press. https:/ / doi.org/10.5949/liverpool/9781781381595.003.0012

Warren, K. (2009). An Unconventional History of Western Philosophy: Conversations between men and women philosophers. Lanham, MD: Rowman and Littlefield.

Worden, N. (2009). The Changing Politics of Slave Heritage in the Western Cape, South Africa. The Journal of African History, 50(1), 23-40. https:/ / doi.org/10.1017/S0021853709004204

Wynter, S. (2000). Unsettling the Coloniality of Being/Truth/Freedom: Towards the Human, after Man: Its Overrepresentation. Unpublished paper presented at the Colonial Working Group Conference, 'Unsettling the Coloniality of Power'.

Citation: Bennett, J. (2021). Searching for Ethical Hope: Ideas on what Feminist Debates on the Anthropocene can offer Theorisations of Gender and Violence. Feminist Encounters: A Journal of Critical Studies in Culture and Politics, 5(1), 04. https://doi.org/10.20897/femenc/9741

Copyright (C) 2021 by Author/s and Licensed by Lectito BV, Netherlands. This is an open access article distributed under the Creative Commons Attribution License which permits unrestricted use, distribution, and reproduction in any medium, provided the original work is properly cited. 